\title{
SS18L1/SSX1 Fusion Protein
}

National Cancer Institute

\section{Source}

National Cancer Institute. SS18L1/SSX1 Fusion Protein. NCI Thesaurus. Code C101073.

A fusion protein encoded by the SS18L1/SSX1 fusion gene. This protein is comprised of all but the last 8 amino acids of the calcium-responsive transactivator protein fused to 78 amino acids from the C-terminus of protein SSX1. 